\title{
PENDAMPINGAN USAHA KECIL DAN MENENGAH TENUN IKAT TROSO DALAM PENINGKATAN PRODUKTIVITAS DAN KUALITAS PRODUK KAIN
}

\section{SMALL AND MEDIUM BUSINESS ASSISTANCE WEAVING IKAT TROSO IN PRODUCTIVITY IMPROVEMENT AND QUALITY OF FABRICS PRODUCTS}

\author{
${ }^{1)}$ Hadi Ismanto, ${ }^{2)}$ Muhammad Husni Tamrin, ${ }^{3}$ Silviana Pebruary \\ ${ }^{1,2)}$ Program Studi Manajemen, ${ }^{3}$ Program Studi Ekonomi Islam \\ Universitas Islam Nahdlatul Ulama Jepara \\ Jl. Tamansiswa (Pekeng) Tahunan Jepara \\ Email: hadifeb@unisnu.ac.id
}

\begin{abstract}
ABSTRAK
Kegiatan ini bertujuan untuk meningkatkan kuantitas dan kualitas produk kain yang dihasilkan oleh mitra, dan meningkatkan jalur pemasaran yang dapat digunakan oleh mitra dalam meningkatakan penjualan kain tenun ikat torso. Metode yang digunakan adalah penampingan, pelatihan, dan praktek langsung oleh mitra UMKM Tenun Ikat Troso Jepara. Capain kegiatan ini adalah dimilikinya alat tenun bukan mesin yang telah ditambah alat jangkar untuk memproduksi varian kain yang berbeda dengan kain yang selama ini diproduksi oleh mitra. Mitra memiliki standar operasi prosedur (SOP) produksi untuk menjaga kualitas kain yang diproduksi. Mitra memiliki jalur pemasaran baru melalui online marketing dengan memanfaatkan website dan social media guna meningkatkan daya saing UMKM.
\end{abstract}

Kata kunci: Pendampingan, Pelatihan, UMKM, Tenun Ikat.

\begin{abstract}
This activity aims to improve the quantity and quality of woven fabric, and improve the marketing channels that can be used by partners in increasing sales. The method used is direct mentoring, training, and practice by SME's partners Tenun Ikat Troso Jepara. Achievement this activity are owned ATBM that have been added jangkar tool to produce variants of different fabrics with fabric that had been produced by partners. Partners have standard operating procedure (SOP) production to maintain the quality of fabric produced. Partners have new marketing channels through online marketing by utilizing websites and social media to improve the competitiveness of SMEs.
\end{abstract}

Keyword: Mentoring, Training, SME, Weaving ikat

Submited : 5 Oktober 2017

Revision : 24 Februari 2018

Accepted : 5 Maret 2018

\section{PENDAHULUAN}

Tenun Ikat Troso merupakan kriya tenun Jepara tepatnya dari Desa Troso. Berupa kain yang ditenun dari helaian benang pakan atau benang lungsin yang sebelumnya diikat dan dicelupkan ke dalam zat pewarna alami. Alat tenun yang dipakai adalah alat tenun mesin (ATBM). Dalam perkembangannya kain tenun ikat tradisional ini telah berkembang menjadi industii rumah tangga yang telah memberikan kontribusi besar dalam penyerapan tenaga kerja dan ekonomi di Kabupaten Jepara.

Tenun ikat Troso merupakan industri kreatif yang mencerminkan kemandirian masyarakat Desa Troso. Industri kreatif adalah industri yang berasal dari 
Hadi Ismanto, Muhammda Husni Tamrin, Silviana Pebruary

pemanfaatan kreativitas, keterampilan serta bakat individu untuk menciptakan kesejahteraan serta lapangan pekerjaan dengan menghasilkan dan mengeksploitasi daya kreasi dan daya cipta individu (Definisi industri kreatif oleh Kementerian Perdagangan RI). Menurut (Alamsyah, Indrahti, \& Maziyah, 2013) industri kreatif adalah kelanjutan tradisi kreativitas ekonomi masyarakat sehingga dapat teridentifikasi secara historis termasuk nilai-nilai budaya yang melatarbelakangi kehadiran industri kreatif.

Data (Badan Pusat Statistik, 2017) memperlihatkan bahwa di Kabupaten Jepara memiliki berbagai jenis UMKM yang tersebar diseluruh wilayah Jepara. Furniture Kayu, makanan, konveksi, tenun ikat dan genteng merupakan sektor UMKM yang memberikan kontribusi terbesar dalam menyerap tenaga kerja di Jepara. Dilihat dari data BPS Kabupaten Jepara tahun 2015 jenis usaha tenun ikat memiliki 325 unit usaha dan 4.978 orang tenaga kerja. Usaha itu berada di posisi kedelapan dari berbagai jenis unit usaha dan berada di posisi keempat dilihat dari serapan tenaga kerjanya yang ada di Jepara. Hal ini memberikan gambaran bahwa usaha tenun ikat troso memiliki peluang berkembang lebih baik dan menyerap tenaga kerja lebih banyak.Adapun data jenis industri kecil menengah di Kabupaten Jepara terdapat pada table berikut :
Tabel 1. Data Jenis Industri Kecil Menengah di Jepara

\begin{tabular}{|c|c|c|c|}
\hline No. & $\begin{array}{l}\text { Jenis } \\
\text { Industri } \\
\text { Kecil } \\
\text { Menengah } \\
\text { (IKM) } \\
\end{array}$ & $\begin{array}{l}\text { Unit } \\
\text { Usaha }\end{array}$ & $\begin{array}{l}\text { Tenaga } \\
\text { Kerja }\end{array}$ \\
\hline 1 & $\begin{array}{l}\text { Furniture } \\
\text { kayu }\end{array}$ & 4,104 & 54,400 \\
\hline 2 & Makanan & 2,029 & 9,586 \\
\hline 3 & Konveksi & 963 & 5,447 \\
\hline 4 & Tenun Ikat & 325 & 4,978 \\
\hline 5 & Genteng & 794 & 4,296 \\
\hline 6 & $\begin{array}{l}\text { Kerajinan } \\
\text { Rotan }\end{array}$ & 524 & 2,890 \\
\hline 7 & $\begin{array}{l}\text { Kerajinan } \\
\text { Kayu }\end{array}$ & 369 & 2,421 \\
\hline 8 & Bordir & 308 & 1,950 \\
\hline 9 & Monel & 473 & 992 \\
\hline 10 & Rokok Kretek & 13 & 381 \\
\hline 11 & Gerabah & 57 & 215 \\
\hline
\end{tabular}

Sumber: BPS Kabupaten Jepara 2017

Tenun ikat Troso merupakan keterampilan yang diturunkan dari beberapa generasi yang dikembangkan oleh penduduk Desa Troso. Keterampilan dalam membuat tenun ikat telah berkembang dari mulai tenun "Gendong" kemudian berkembang dengan menggunakan alat yang dapat menghasilkan kain lebih baik dan lebih cepat.Desa Troso terletak disebelah barat Kecamatan Pecangaan merupakan daerah dataran rendah dan memiliki kondisi alam yang mendukung dalam usaha tenun ikat, daerah yang memiliki air yang bersih dan banyak, suhu panas yang mendukung untuk proses pengeringan dalam proses produksi kain tenun ikat.

Perkembangan tenun ikat Troso mengalami peningkatan dari tahun ke tahun baik dari jumlah tenaga kerja yang terserap ataupun jumlah pelaku atau pemilik usaha tenun ikat. Akan tetapi perkembangan UMKM Troso yang pesat dibarengi dengan berbagai kendala dan 
permasalahan klasik UMKM yaitu persaingan tidak sehat yang dapat menurunkan harga jual dan permintaan kain tenun ikat itu sendiri. Selain itu tidak memiliki konsistensi dalam menjaga kualitas barang, hal ini terbukti ketika permintaan pasar tinggi, pengrajin mengambil jalan pintas dengan mengganti bahan dengan kualitas lebih rendah guna mendapat untung yang lebih besar. Hal ini membuat pasar kurang percaya dengan kualitas kain tenun ikat troso. Selain itu berbagai keterbatasan kendala yang di miliki UMKM tenun ikat Troso antara lain: lemahnya permodalan, kurangnya kemampuan kewirausahaan, teknik produksi masih sederhana, serta terbatasnya kemampuan manajemen.

Selain banyaknya permasalah diatas, UMKM tenun ikat Troso belum memiliki standard kualitas maupun produktivitas, dimana dalam persaingan pada era globalisasi saat ini UMKM dituntut untuk selalu meningkatkan kinerja dan produktivitasnya. Sehingga UMKM dituntut untuk selalu memperbaiki proses produksi secara berkesinambungan agar tercapai peningkatan kualitas dan produktivitas tersebut.

Dalam penelitian Feigenbaum (1992) dalam (Parwati \& Sakti, 2012) kualitas produk (barang/jasa) merupakan faktor dasar kepuasan konsumen dalam menentukan produk yang akan dibeli atau dipakai. Sehingga kualitas dari produk merupakan faktor kunci bagi keberhasilan perusahaan. Faktor-faktor yang berpengaruh terhadap kualitas biasa disebut sebagai 9M yang meliputi: Market (pasar), Money (uang), Management (manajemen), Man (manusia), Motivation (motivasi), Material (bahan), Machines and Machanization (mesin dan mekanisasi), Modern Information Methods (metode informasi modern), Mounting Product Requirements (persyaratan proses produksi).
Kualitas merupakan keseluruhan ciri serta sifat dari suatu produk atau pelayanan yang berpengaruh pada kemampuan untuk memuaskan kebutuhan yang dinyatakan atau yang tersirat (Kotler, 2005). Menurut (Kotler \& Amstrong, 2008) kualitas produk adalah kemampuan sebuah produk dalam memperagakan fungsinya, hal itu termasuk keseluruhan durabilitas, reliabilitas, ketepatan, kemudahan pengoperasian dan reparasi produk juga atribut produk lainnya. Pelanggan mendifinisikan kualitas dengan berbagai cara melalui pemenuhan harapan pelanggan. (Heizer \& Render, 2004) mendefinisikan kualitas sebagai kemampuan produk dan jasa memenuhi kebutuhan pelanggan.

Kegiatan ini bertujuan untuk menigkatkan kuantitas dan kualitas produk kain yang dihasilkan oleh mitra yang memiliki prospek ekspor dengan menjawab berbagai permasalahan yang ada pada mitra pengabdi, diantaranya:

1. Dari aspek produksi, mitra saat ini masih menggunakan alat tenun bukan mesin yang hanya dapat memproduksi jenis kain tradisional dengan pola dari ikatan pada pakan dan belum memiliki varian kain yang memiliki pola yang timbul dari kain.

2. Mitra belum memilliki standar operasional prosedur dalam setiap tahapan kegiatan atau operasional dalm memproduksi kain tenun ikat. Karyawan dalam melaksanakan kegiatannya berdasarkan arahan langsung pemilik. Sehingga ketika pemilik pergi terkadang pekerja tidak bekerja sesuai dengan yang diinginkan atau yang diarahkan pemilik, sehingga kualitas warna tidak sama.

3. Sistem pemasaran masih mengandalkan sistem tradisonal, dimana pemilik langsung turun ke pasar untuk memasarkan produknya, dan juga mengandalkan pedagang besar yang menjadi mitra dalam pemasaran. 


\section{METODE}

Kegiatan ini dilaksanakan untuk dapat mengembangkan usaha UMKM tenun ikat troso yang akan bertindak sebagaisalah ujung tombak pembangunan ekonomi di masyarakat Jepara, sehingga UMKM tenun ikat troso dapat berkembang dan maju dengan adanya perbaikan yang terus menerus, adapun mekanisme yang akan dilakukan meliputi tahapan sebagai berikut:

\section{Modifikasi Alat Produksi}

Langkah pertama yang dilakukan dalam memodifikasi alat tenun adalah dengan melakukan pemilihan Alat yang dapat dimodifikasi dengan menambahkan mesin pada alat tenun bukan mesin, hal ini perlu dilakukan karena aka nada penyesuaian alat dengan bahan baku yang diproduksi, sehingga perlu di setting agar hasil dari alat tersebut dapat menghasilkan kain yang berkualitas tinggi. Setelah dilakukan penambahan alat jagkar pada ATBM maka dilakukan uji coba mesin tanpa benang, setelah dapat berjalan dengan baik, maka diilakukan penyesuaian dengan benang yang akan diproduksi, hal ini sangat menentukan berhasil atau tidaknya mesin yang akan dipakai nantinya. Untuk itu perlu adanya kemampuan setting alat yang baik guna dapat menghasilkan kain yang dapat diproduksi.

\section{Penyusunan SOP Produksi}

Dalam menyusun SOP produksi terlebih dahulu dilakukan analisis proses produksi yang ada di tiga mitra UMKM tenun ikat troso. Dengan melihat situasi proses situai produksi dan kondisi pekerjaan yang dilaksanakan oleh ketiga mitra UMKM troso, maka tim akan dapat menyusun SOP Produksi yang bagi ketiga mitra UMKM. Dalam proses penyusunan SOP Produksi tim akan selalu berkomunikasi dengan pemilik UMKM untuk menyesuaikan kondisi pekerjaan dalam proses produksi mulai dari pembuatan lusi, yang dimulai dari proses ngeteng, proses nali, sampai proses ngebom. Setelah melakukan penyusunan maka tim akan melakukan sosialisasi pada Mitra UMKM. Sosialisasi ini diharapkan akan meningkatkan pengetahuan dan pemahaman akan pentingnya SOP yang diterapkan bagi usaha, karena selama ini UMKM tidak memiliki SOP yang dapat diterapkan dalam operasi usaha sehingga didapatkan standar kualitas yang sesuai dengan yang diharapkan. Setalah melakukan sosialisasi pada mitra, maka SOP tersebut diserahkan dan dilakukan pendampingan agar dalam penerapan atau pelaksanaan SOP Produksi tersebut dapat berjalan dengan baik

\section{Pembuatan Media Online Marketing}

Tim memberikan perlatan dan media online marketing melalui beberapa media social dan membuat website dengan membeli domain. Tim memberikan pelatihan dan buku paduan dalam mengelola online marketing agar terjadi transfer knowledge dengan baik, sehingga mitra dapat membuka jalan pemasaran secara langsung pada pengguna kain (end user).

Adapaun kegiatan yang dilakukan tim pengabdi diantaranya:

a. Membangun Pondasi Online Shop, yaitu menggunakan website sebagai toko utama. Nantinya, website ini akan dijadikan sebagai lapak online atau workshop "resmi"mitra di dunia maya. Selain itu, website ini juga kita jadikan sebagai pusat tempat rujukan ketika kita hendak menyebar promosi online lewat social media, forum, marketplace, ataupun situs jualan lainnya.Tim pengabdi membuat website sebagai rujukan utama. Karena terkadang 
website ini juga bisa dijadikan parameter apakah seseorang itu serius dalam menjalani bisnis online atau tidak. Dengan memiliki website, biasanya orang lain akan menjadi lebih mantab ketika hendak bertransaksi dengan UMKM mitra sehingga daya ungkit bisnis dan promosi akan lebih optimal.

b. Social Media Marketing. Setelah toko online utama mitra terbentuk dan sudah terisi oleh produk-produk yang ditawarkan, sebagai penjual mitra harus mengundang pembeli supaya datang. Untuk itu tim akan memberikan pelatihan dan pendampingan agar mitra dapat masuk ke tempat yang banyak orang bersosialisasi atau social media. Peran Social mediadisini adalah sebagai sarana pemasaran dan komunikasi dengan kustomer, dan bukan sebagai tempat jualan utama. Sehingga mitra akan mengundang mereka ke website utama untuk membeli

\section{HASIL DAN PEMBAHASAN}

\section{Modifikasi Alat Produksi}

Tim bekerjasama dengan ahli pembuat alat tenun bukan mesin (ATBM) memodifikasi dengan penambahan jangkar sebagai alat penambahan motif pada kain selain motif dari hasil ikat. Penambahan motif ini diharapkan menambah diversifikasi dari kain yang dihasilkan, sehingga mitra dapat melayani berbagai permintaan model kain yang diperlukan oleh pelanggan. Alat tenun bukan mesin yang telah dimodifikasi langsung diserahkan kepada mitra untuk dapat digunakan, sehingga mitra dapat meningkatkan produksinya. Gambar 1 menunjukkan alat tenun bukan mesin yang telah ditambahkan mesin jangkar.

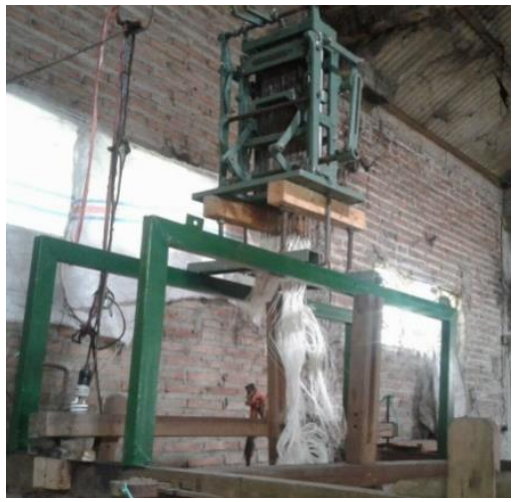

Gambar 1. Pemasangan Alat Jangkar

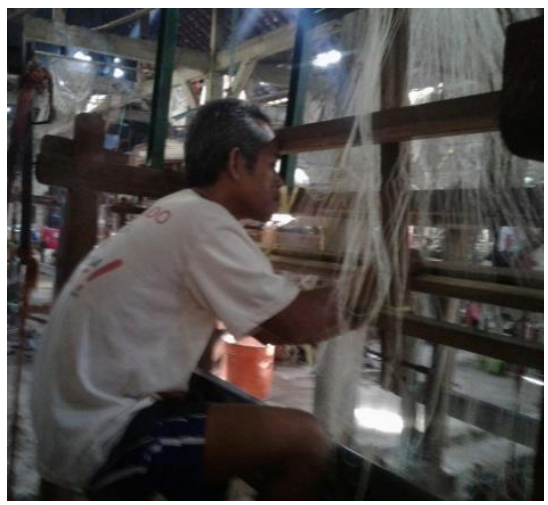

Gambar 2. Setting Alat Tenun

Penambahan alat jangkar tenun merupakan salah satu solusi yang dapat dilaksanakan oleh tim pengabdi dalam mengatasi permasalahan model kain tenun ikat torso Jepara. Penambahan alat tersebut dapat meningkatkan produktivitas dan variasi kain yang dihasilkan guna memebuhi permintaan pasar. Peningkatan produktivitas kain dapat dilakukan dengan penambahan alat produksi yang dimodifikasi menjadi alat otomatis (Akbari, Dehghan, Azmoon, \& Forouharmajd, 2013). Selain dengan penambahan mesin pada alat produksi produktivitas juga dapat ditingkatkan dengan kesadaran karyawan dan pemilik untuk meningkatkan kesehatan kerja, hal ini sesuai dengan penelitian Ukhisia, Astuti, \& Hidayat(2013) yang menunjukkan bahwa kesehatan kerja memiliki pengaruh positif dan 
signifikan terhadap produktivitas karyawan. Produktivitas karyawan tenun sangat bergantung pada kesehatan karyawan, karena produksi tenun masih mengandalkan tenaga manusia dalam memproduksi kain.

Penelitian Zamzam, Mohammadzadeh, \& Rezaian (2014) menemukan bahwa produktivitas dapat dipengaruhi oleh total quality management. Peningkatan produktivitas diharapkan dapat meningkatkan produk yang tersedia untuk dijual, hal ini juga dapat meningkatkan penjualan dan meningkatkan keuangan perusahaan.

\section{Menyusun SOP Produksi}

Penyusunan SOP Produksi dimulai dengan menggali informasi tentang proses produksi yang ada pada mitra. Setelah mendapat informasi yang cukup tim dibantu mahasiswa sabagai staf pembantu menyusun alur proses produksi. Tim beberapa kali berkomunikasi dengan mitra menanyakan alur produksi yang benar. SOP yang dikerjakan sampai laporan kemajuan ini dibuat baru sampai pada alur atau proses produksi yang masih membutuhkan penyempurnaan secara detail dari masing-masing tahap proses produksi. SOP yang dibuat meliputi SOP pembuatan lusi dan SOP pembuatan pakan baik untuk produk jenis kain ikat CSM dan SOP pembuatan lusi kain bangket. Sehingga SOP yang dihasilkan adalah 1) SOP Pembuatan Lusi Blangket, 2) SOP Pembuatan Lusi Ikat CSM, dan 3) SOP Pembuatan Pakan Ikat CSM. SOP yang disusun belum diserahkan kepada mitra karena masih dibutuhkan penyempurnaan pada detail setiap proses produksi.

Penyusunan SOP ini diharapkan membawa dampak pada berkurangnya risiko pada proses pembuatan kain tenun ikat di mitra, dan memudahkan pendataan oleh mitra. Hal ini sesuai dengan penelitian Prasetya, Rochim, \& Windasari(2015) yang mengidentifikasi risiko aset dengan menggunakan ISMS ISO 27001, dimana aset data lebih berisiko dibandingkan aset tetap. Selain itu dengan dimilikinya SOP diharapkan mampu mengambil keputusan yang tepat, karena memiliki data yang akurat sehingga memdukung dalam pengambilan keputusan, hal ini sesuai dengan penelitian Sriyadi, Istiyanti, \& Fivintari (2015) yang meneliti SOPGAP usaha tani di kabupaten bantul, dimana terdapat korelasi positif dan signifikan antara tingkat keputusan petani berusahatani organik dengan tingkat penerapan Standar Operating Prosedure - Good Agriculture Practise (SOP-GAP) usahatani padi organik.

SOP yang disusun juga dapat meningkatkan kualitas dari produk kain yang dihasilkan mitra. Kualitas kain yang selama ini kurang konsisten dapat lebih konsisten dengan penerapan SOP produksi. Hal ini sesuai dengan artikel Haryanto, Nawansih, \& Nurainy (2013) yang melakukan pengabdian pada industri kripik pisang, dimana draft SOP yang disusun mampu meningkatkan kualitas kripik pisang sehingga sesuai dengan persyaratan mutu SNI 01-4315-1996.

Penerapan SOP pada usaha kecil menengah (UKM) menjadi tantangan bagi pengabdi, karena UKM tidak tertarik untuk melaksanakan kegiatan yang terorganisir dengan baik, mereka lebih banyak melaksanakan dengan pemilik sebagai pengendali dan pusat pengembil keputusan, hal ini sesuai dengan penelitian Adamczak, Domański, \& Cyplik(2013) yang menemukan usaha kecil tidak tertarik menerapkan SOP karena sentralisasi 
Hadi Ismanto, Muhammda Husni Tamrin, Silviana Pebruary Pendampingan Usaha Kecil dan Menengah Tenun Ikat Troso dalam Peningkatan Produktivitas dan Kualitas Produk Kain

operasi dan pengambilan keputusan, sedangkan usaha menengah tertarik permasalahan yang dihadapi dan dapat menerapkan SOP karena kompleksitas diselesaikan dengan pemanfaatan SOP.

\section{Alur Produksi Pembuatan Kain CSM}

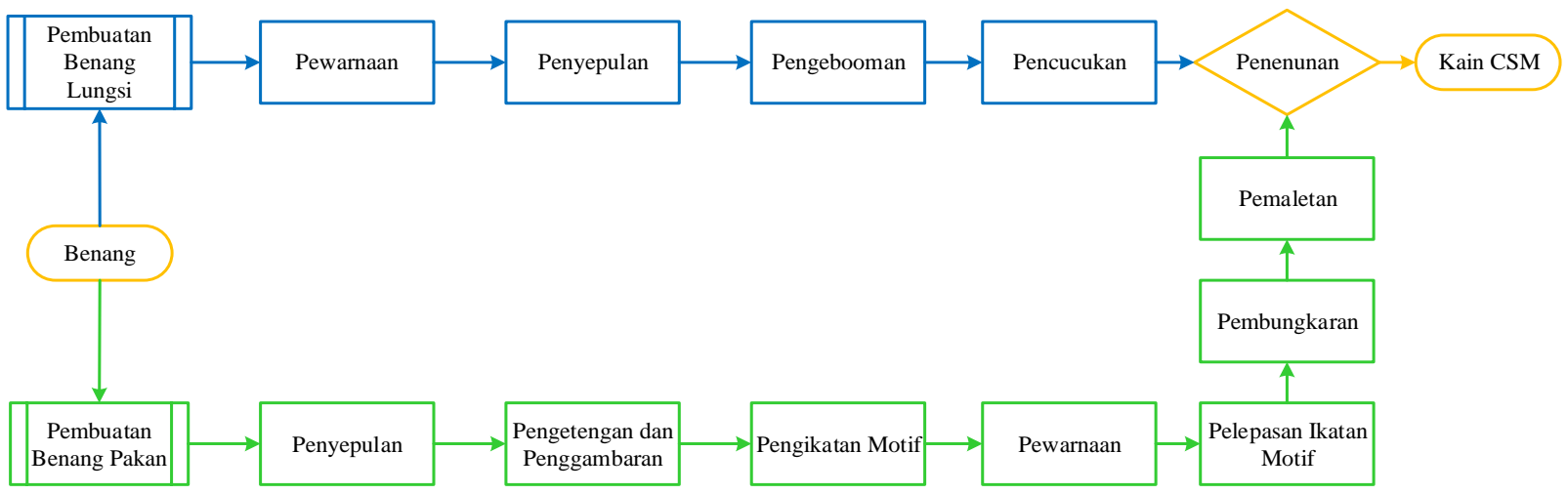

Gambar 3. Alur Proses Produksi Kain CSM

Alur Produksi Pembuatan Lungsi Kain CSM

\begin{tabular}{|c|c|c|c|c|c|}
\hline \multirow[t]{8}{*}{$\begin{array}{c}\text { Bagian Gudang } \\
\text { (Persediaan) }\end{array}$} & $\begin{array}{c}\text { Bagian } \\
\text { Pewarnaan }\end{array}$ & $\begin{array}{c}\text { Bagian } \\
\text { Penyepulan }\end{array}$ & $\begin{array}{c}\text { Bagian } \\
\text { Pengebooman }\end{array}$ & $\begin{array}{c}\text { Bagian } \\
\text { Pencucukan }\end{array}$ & $\begin{array}{c}\text { Bagian } \\
\text { Penenunan }\end{array}$ \\
\hline & $\begin{array}{c}\text { Benang } \\
\text { direndam }\end{array}$ & & & & \\
\hline & \begin{tabular}{|c|}
\multicolumn{1}{c|}{} \\
Pencampuran \\
wenter (pewarna) \\
dengan air panas
\end{tabular} & & & \begin{tabular}{|c|} 
Pemotongan \\
benang lama pada \\
Alat Tenun \\
\end{tabular} & $\begin{array}{c}\text { Kain dilepas dari } \\
\text { penggulung sesuai } \\
\text { panjang kain yang } \\
\text { diinginkan }\end{array}$ \\
\hline & $\begin{array}{l}\text { Pencelupan benang } \\
\text { pada air wenter }\end{array}$ & $\begin{array}{c}\text { Benang } \\
\text { dimasukkan } \\
\text { dalam Inoan }\end{array}$ & & $\begin{array}{c}\text { boom tenun } \\
\text { baru }\end{array}$ & Penenunan \\
\hline & $\begin{array}{c}\text { Pemerasan benang } \\
\text { (Pengeringan) }\end{array}$ & $\begin{array}{l}\text { Benang digulung } \\
\text { pada sepulan }\end{array}$ & $\begin{array}{c}\text { Sepulan } \\
\text { disusun pada } \\
\text { rak (skesel) }\end{array}$ & $\begin{array}{c}\text { Benang boom baru } \\
\text { dimasukkan pada } \\
\text { gun dan sisir }\end{array}$ & $\begin{array}{c}\text { Penyesuaian benang } \\
\text { pakan pada jalur } \\
\text { benang lungsi }\end{array}$ \\
\hline & Pembilasan benang & & $\begin{array}{l}\text { Benang digulung } \\
\text { pada boom }\end{array}$ & & \\
\hline & I & & & & pada Sekoci \\
\hline & Penjemuran & & & & \\
\hline
\end{tabular}

Gambar 4. SOP Pembuatan Lungsi Ikat CSM 
Hadi Ismanto, Muhammda Husni Tamrin, Silviana Pebruary Pendampingan Usaha Kecil dan Menengah Tenun Ikat Troso dalam Peningkatan Produktivitas dan Kualitas Produk Kain

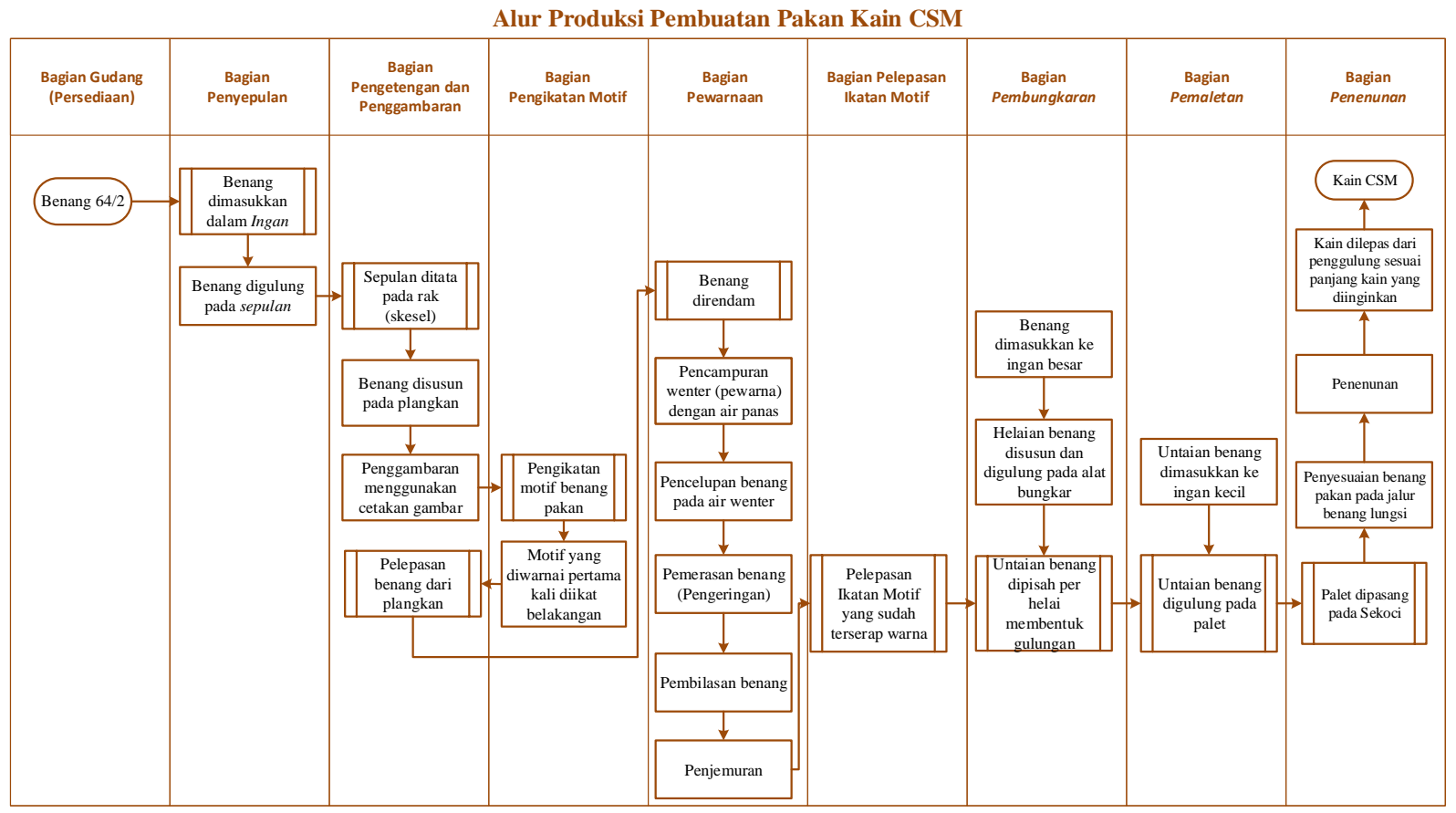

Gambar 5. SOP Pembuatan Pakan Ikat CSM

\section{Alur Produksi Pembuatan Kain Blanket}

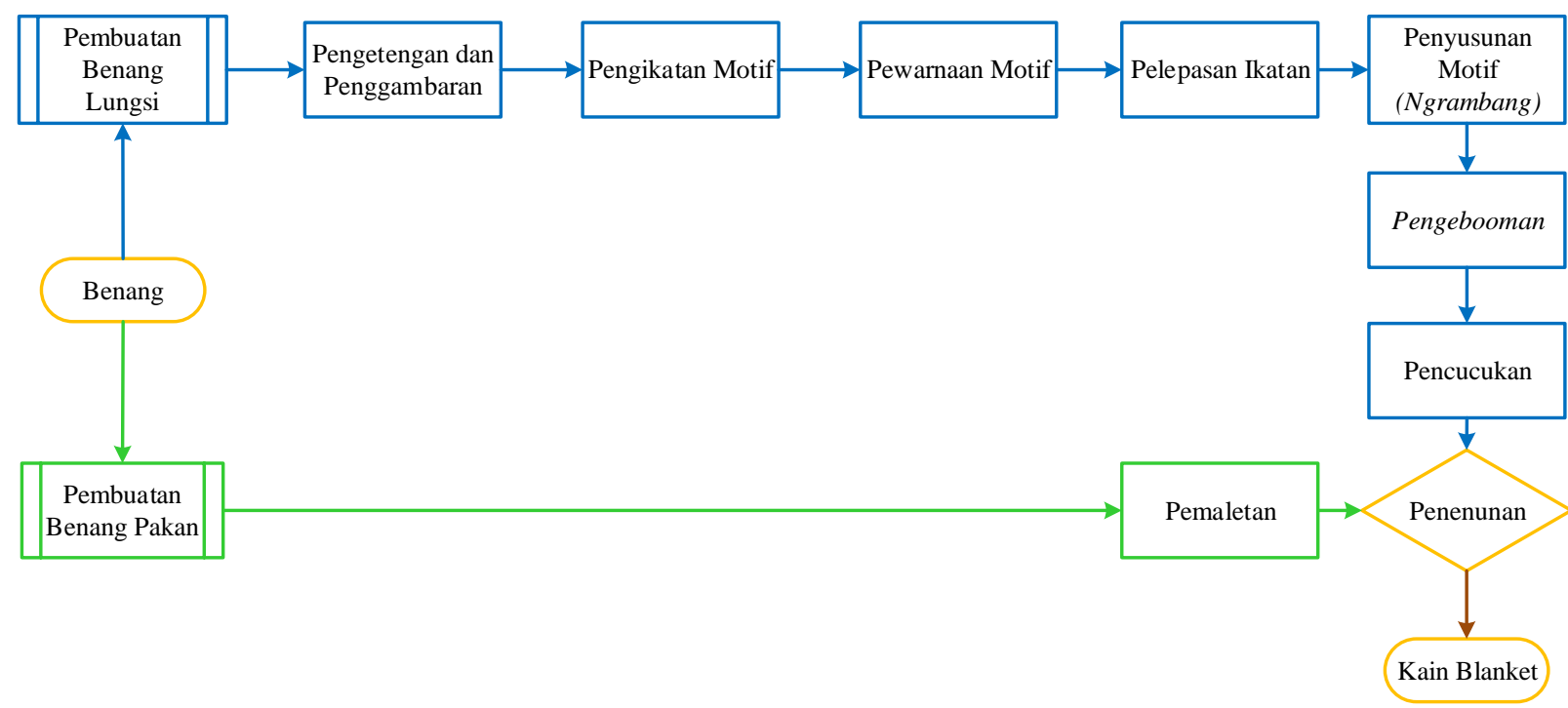

Gambar 6. Alur Proses Produksi Kain Blangket 


\section{Hadi Ismanto, Muhammda Husni Tamrin, Silviana Pebruary \\ Pendampingan Usaha Kecil dan Menengah Tenun Ikat Troso dalam Peningkatan \\ Produktivitas dan Kualitas Produk Kain}

\section{Menyusun Media Pemasaran Online}

Tim pengabdi membangun pondasi Online Shopterlebih dahulu sebelum berbagai media dimanfaatkan untuk menunjang penjualan. Pondasi yang dimaksud adalah tim pengabdi membangun website yang akan dijadikan sebagai lapak online atau workshop "resmi"mitra di dunia maya. Selain itu, website ini juga kita jadikan sebagai pusat tempat rujukan ketika kita hendak menyebar promosi online lewat social media, forum, marketplace, ataupun situs jualan lainnya. Beberapa kegiatan dalam membangun website yang telah dilakukan antara lain :

a. Menentukan Nama Domain dan Hosting, yaitu tempatnya website mitra ditaruh. Semua file-file yang berhubungan dengan website akan ditaruh dan disimpan di hosting. Dan agar orang lain bisa mengakses website mitra, maka orang-orang akan mengetik nama domain mitra di browsernya. Dengan kata lain, domain adalah alamat virtual toko mitra. Adapun alamat web dari masing-masing mitra adalah www.handikajaya.id, www.kencanaindah.com, dan www.makmurputra.com.

b. Isikan Konten Website. Setelah instalasi berhasil, tim sudah mulai bisa mengisikan informasi produk mitra ke website utama kita.

Kegiatan yang dilakukan tim pengabdi dengan harapan memiliki dampak pada peningkatan kualitas dan peningkatan produktivitas bagi mitra, sehingga akan menimbulkan dampak pada peningkatan kesejahteraan mitra dan masyarakat desa Troso yang memiliki usaha kerajinan tenun ikat semakin berkembang. Mitra pengabdi dapat memanfaatkan hasil kegiatan secara baik agar dapat meningkatkan daya saing produk, sumber daya manusia, maupun manajemen usaha guna meningkatkan kesejahteraan UMKM. UMKM yang identik dengan berbagai permasalahan pengelolaan diharapkan semakin berkurang dengan adanya kegiatan pengabdian semacam ini.

Penyusunan media pemasaran online dapat memudahkan pelanggan dalam mengakses informasi selama 24 jam dan dari manapun serta mendapat pelayanan lebih optimal, hal ini sesuai dengan penelitian Himawan, Saefullah, \& Santoso (2014) yang meniliti pada CV. Selaras Batik. Himawan et al., (2014) mengatakan website yang dirancang dapat meningkatkan penghasilan usaha dagang CV Selaras Batik, karena penghasilan tidak lagi bersumber dari toko saja tetapi juga melalui pemasaran online.

Media pemasaran online yang dibangun juga memperhatikan tampilan yang menarik agar konsumen lebih tertarik untuk melihat produk yang ditawarkan. Penelitian Wijaya \& Jasfar (2014) menemukan bahwa terdapat pengaruh signifikan website design terhadap pembelian melalui onlineshopping, karena konsumen lebih senang mengunjungi situs online shop yang memiliki website design yang menarik dan mudah dimengerti.

\section{SIMPULAN}

Hasil pelaksanaan kegiatan pengabdian masyarakat dapat disimpulkan:

1. Program modifikasi alat tenun telah berjalan dengan baik, mitra telah memanfaatkan alat tenun bukan mesin dengan penambahan jangkar untuk memproduksi kain dengan model yang berbeda, sehingga menambah diversifikasi produk yang dihasilkan.

2. Program penyusunan SOP Produksi bermanfaat bagi mitra untuk menjaga 
Hadi Ismanto, Muhammda Husni Tamrin, Silviana Pebruary

konsistensi kualitas kain yang diproduksi, sehingga dapat menjaga kepercayaan pelanggan baik nasional maupun internasional.

3. Program pembuatan media pemasaran oline dirasakan oleh mitra dengan meningkatnya jalur pemasaran yang selama ini hanya mengandalkan pemasaran face to face, sehingga dapat mempercepat proses transaksi yang dapat dilakukan oleh mitra dengan pelanggannya.

Adamczak, M., Domański, R., \& Cyplik, P. (2013). Use of Sales And Operations Planning in Small and Medium-Sized Enterprises. Log Forum: Scientific Journal of Logistics, 9(1), 11-19.

Akbari, J., Dehghan, H., Azmoon, H., \& Forouharmajd, F. (2013). Relationship between lighting and noise levels and productivity of the occupants in automotive assembly industry. Journal of Environmental and Public Health, 2013. https://doi.org/10.1155/2013/527078

Alamsyah, Indrahti, S., \& Maziyah, S. (2013). Kearifan Lokal Pada Industri Tenun Troso: Potret Kewirausahaan Pada Masyarakat Desa (1st ed.). Semarang: CV Madina.

Badan Pusat Statistik. (2017). Banyaknya Unit Usaha (unit) dan Tenaga Kerja (orang) Dirinci Menurut Jenis Industri Kecil Menengah di Kabupaten Jepara (IKM), 2015. Retrieved from https://jeparakab.bps.go.id/linkTabelS tatis/view/id/489

Haryanto, D., Nawansih, O., \& Nurainy, F. (2013). Penyusunan Draft Standard Operating Procedure (SOP) Pengolahan Keripik Pisang (Studi Kasus di Salah Satu Industri Rumah Tangga Keripik Pisang Bandar

\section{UCAPAN TERIMA KASIH}

Kami mengucapkan terima kasih kepada Direktorat Riset Dan Pengabdian Masyarakat, Direktorat Jenderal Penguatan Riset Dan Pengembangan, Kementrian Riset, Teknologi, Dan Pendidikan Tinggi, LPPM Unisnu Jepara, dan Seluruh pegiat pengabdian yang telah membantu terlaksanannya kegiatan pengabdian ini

\section{DAFTAR PUSTAKA}

Lampung). Jurnal Teknologi Industri Dan Hasil Pertanian, 18(2), 132143.

Heizer, J., \& Render, B. (2004). Operations Management (7th ed.). New Jersey: Pearson Education, Inc,.

Himawan, Saefullah, A., \& Santoso, S. (2014). Analisa dan Perancangan Sistem Informasi Penjualan Online ( E- Commerce ) pada CV Selaras Batik Menggunakan Analisis Deskriptif. Scientific Journal of Informatics, 1(1), 53-64. https://doi.org/10.15294/sji.v1i1.3641

Kotler, P. (2005). Manajemen Pemasaran (11th ed.). Jakarta: PT. Indeks Kelompok Gramedia.

Kotler, P., \& Amstrong, G. (2008). Prinsip-Prinsip Pemasaran. Jakarta: Erlangga.

Parwati, C. I., \& Sakti, R. M. (2012). Pengendalian Kualitas Produk Cacat Dengan Ppendekatan Kkaizen dan Analisis Masalah dengan Seven Tools. In Seminar Nasional Aplikasi Sains \& Teknologi (SNAST) Periode III (pp. 16-24).

Prasetya, P., Rochim, A. F., \& Windasari, I. P. (2015). Desain dan Implementasi Standar Operasional Prosedur (SOP) Keamanan Sistem Informasi Fakultas Teknik Universitas Diponegoro 
Hadi Ismanto, Muhammda Husni Tamrin, Silviana Pebruary

Menggunakan Standar ISO 27001. Jurnal Teknologi Dan Sistem Komputer, 3(3), 387-392. https://doi.org/10.14710/jtsiskom.3.3. 2015.387-392

Sriyadi, Istiyanti, E., \& Fivintari, F. R. (2015). Evaluasi Penerapan Standard Operating Procedure-Good Agriculture Practice (SOP-GAP) pada Usahatani Padi Organik di Kabupaten Bantul. AGRARIS: Journal of Agribusiness and Rural Development Research, 1(2), 78-84. https://doi.org/10.18196/agr.1211

Ukhisia, B. G., Astuti, R., \& Hidayat, A. (2013). Analisis Pengaruh Keselamatan dan Kesehatan Kerja Terhadap Produktivitas Karyawan
Dengan Metode Partial Least Square. Jurnal Teknologi Pertanian, 14(2), 95-104.

Wijaya, M., \& Jasfar, F. (2014). Pengaruh Rancangan Situs, Harga, Kepercayaan dan Keamanan Terhadap Pembelian Produk Fashion Melalui Online Shopping. Jurnal Manajemen Dan Pemasaran Jasa, $7(2), 31-62$.

Zamzam, E., Mohammadzadeh, Y., \& Rezaian, F. (2014). The Relationship Between Total Quality Management with Creativity and Productivity at Head Quarter of Youth and Sport Fars Provienc. Advences in Environmental Biology, 8(7), 25622565. 